\title{
Gender and Age Determinants of Psychogenic Movement Disorders: A Clinical Profile of 73 Patients
}

\author{
Nitish Kamble, D.K. Prashantha, Menka Jha, M. Netravathi, \\ Y.C. Janardhan Reddy, Pramod Kumar Pal
}

\begin{abstract}
Background: Psychogenic movement disorders (PMD) is a group of disorders that cannot be attributed to any structural or biochemical abnormality, but has an underlying psychiatric illness. The profile of PMD varies according to country and socioeconomic factors. Methods: The present study reports the clinical profile of patients with PMD from India. Seventy-three patients with documented or clinically established PMD were seen over a period of 14 years with detailed neurological and psychiatric examinations. Results: The mean age at presentation was $29.1 \pm 15.1$ years (women, $51 \%$ ). Approximately $30 \%$ were $\leq 18$ years of age (boys, $63.6 \%$ ). The onset of symptoms was abrupt in $61.6 \%$ and the initial body part most often affected was right upper limb (adults, 29.4\%; children, 31.8\%). Tremor was observed in $31.4 \%$ of adults and $9 \%$ of children, whereas myoclonus was more common in children (36.4\%). Tremors were more often seen in women $(42.3 \%)$ than in men $(20 \%)$, whereas myoclonus was almost equally prevalent in girls $(37.5 \%)$ and boys $(35.7 \%)$. Depression was the most common psychiatric comorbidity (men, 16\%; women, $15.4 \%$ ). About $42.5 \%$ required hospital admission and $57.5 \%$ had significant reduction or complete cessation of PMD after counseling, antidepressants, and/ or placebo. Conclusions: PMD was equally prevalent among women and men. Tremor was most often observed in adults, whereas myoclonus was most often observed in children. Electrophysiology and placebo were useful supplementary tools for diagnosing PMD.
\end{abstract}

RÉSUMÉ: Déterminants des sujets présentant des troubles psychogènes du mouvement selon le sexe et l’âge: profil clinique de 73 patients. Contexte: Les troubles psychogènes du mouvement (TPM) constituent un groupe de problèmes de santé qui ne peuvent être attribués à aucune anomalie structurale ou biochimique et qui sont dus à une maladie psychiatrique sous-jacente. Le profil des TPM varie selon le pays et les facteurs socio-économiques des patients. Méthode: Nous rapportons le profil de patients présentant des TPM en Inde. Soixante-treize patients présentant des TPM documentés ou établis cliniquement ont subi des examens neurologiques et psychiatriques détaillés au cours d'une période de 14 ans. Résultats: L'âge moyen des patients au moment de la consultation initiale était de $29,1 \pm 15.1$ ans et $51 \%$ étaient des femmes. À peu près $30 \%$ étaient âgés de 18 ans ou moins et parmi eux, $63,6 \%$ étaient des garçons. Le début des symptômes avait été soudain chez $61,6 \%$ et la partie du corps initialement touchée était le plus souvent le membre supérieur droit (29,4\% chez les adultes, $31,8 \%$ chez les enfants). Chez les adultes, $31,4 \%$ avaient du tremblement ainsi que $9 \%$ des enfants. La myoclonie était plus fréquente chez les enfants $(36,4 \%)$. Les tremblements étaient plus fréquemment observés chez les femmes $(42,3 \%)$ que chez les hommes (20\%). La myoclonie était presqu'aussi fréquente chez les filles $(37,5 \%)$ que chez les garçons $(35,7 \%)$. La dépression était la comorbidité psychiatrique la plus fréquente tant chez les hommes (16\%) que chez les femmes (15,4\%). Environ 42,5\% des sujets ont dû être hospitalisés et 57,5\% présentaient une diminution significative ou un arrêt complet des TPM suite à une prise en charge psychologique, la prescription d'antidépresseurs et/ou de placebo. Conclusions: La prévalence des TPM était égale chez les femmes et chez les hommes. Le tremblement était le plus souvent observé chez les adultes, alors que la myoclonie était plus souvent observée chez les enfants. L'électrophysiologie et le placebo se sont avéré des outils supplémentaires utiles pour poser un diagnostic de TPM.

Keywords: Dystonia, myoclonus, movement disorder, psychogenic, tremor doi:10.1017/cjn.2015.365

Can J Neurol Sci. 2016; 43: 268-277

\section{INTRODUCTION}

Psychogenic movement disorders (PMD) is a group of disorders that cannot be attributed to any structural or biochemical abnormality, but has an underlying psychiatric illness. PMD is a part of psychogenic neurologic disorders that together accounts for about $1 \%$ to $16 \%$ of all the patients attending neurology outpatient department. ${ }^{1}$ PMD may coexist with organic neurological illness in $10 \%$ to $15 \%$ of patients. ${ }^{2}$ The diagnosis of PMD was that of exclusion, but now with the better understanding of the pathophysiology, clinical characteristics and with the

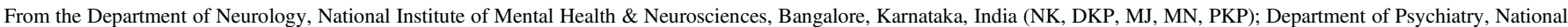
Institute of Mental Health \& Neurosciences, Bangalore, Karnataka, India (YCJR).

Received July 13, 2015. Final Revisions Submitted October 28, 2015.

Correspondence to: Pramod Kumar Pal, Professor, Department of Neurology, National Institute of Mental Health \& Neurosciences, Bangalore-560029, India.

Email: palpramod@hotmail.com 
development of newer techniques, a definitive diagnosis can be made. ${ }^{3,4}$ Clinical criteria, which was initially devised for psychogenic dystonia but later revised to include other movement disorders, have been laid since 1988 by Fahn and Williams. ${ }^{5,6}$

Clinically PMD can present as hyperkinetic disorders and uncommonly hypokinetic disorders. ${ }^{6,7}$ Early diagnosis and appropriate management is essential because it is associated with significant health care cost, poor quality of life, inadvertent medication use with their side effects, and burden to the caregiver. In this study, we have attempted to give a detailed clinical description and outcome of a large cohort of PMD seen in our tertiary care center.

\section{METHODS}

The present study is a detailed report of 73 patients with PMD evaluated between 2000 and 2013 in the departments of neurology and psychiatry at the National Institute of Mental Health and Neurosciences, Bangalore, India. In these 14 years, all patients who were referred or suspected to have PMD were clinically examined both by senior movement disorder specialist (PKP) and an experienced psychiatrist (YCJR) after discussions and relevant investigations. The information regarding the onset and duration of symptoms, precipitating factors, and psychosocial background was obtained from the patient and caregivers and also from the previous medical records when available. All efforts were made to contact the referring physician. Each patient was diagnosed to have either a documented or clinically established PMD based on earlier criteria. ${ }^{5,6}$ PMD that remits with suggestion, psychotherapy, physiotherapy, by administration of a placebo, or a patient free of symptoms when left alone was considered to be documented PMD, whereas patients with inconsistent and incongruent features incompatible with organic disease with or without additional features of "false" signs and multiple somatizations were labeled as clinically established PMD. All patients underwent detailed clinical examination and video documentation after appropriate informed written consent. The types of abnormal movements'topographical distribution were reviewed. In addition, factors such as prior psychiatric illness, antecedent illness, and precipitating factors were also taken into consideration. Antecedent illness was taken as any medical illness that preceded (usually by few days) the onset of PMD. Precipitating factors were stressors that preceded the onset of PMD, ranging from days to weeks.

Psychiatric consultation, clinical course, treatment received, and outcome measures were analyzed for better understanding of the illness and associated psychopathology. When in doubt, patients with suspected PMD were admitted to the ward and appropriate investigations done to rule out an organic disorder. Some patients underwent electrophysiological tests to characterize the abnormal movements.

All the variables were expressed as mean \pm standard deviation, percentage, and range. Chi-square test was used to compare the frequencies between the various groups. All $\mathrm{p}$ values $\leq 0.05$ were considered as statistically significant. Data were analyzed using $\mathrm{R}$ software.

\section{RESULTS}

\section{Demographic Profile}

From 2000 to 2013, 73 patients were diagnosed with PMD; $51(69.9 \%)$ were adults (age, 36.2 \pm 9.2 years) and $22(30.1 \%)$ were children ( $\leq 18$ years) (age, $12.6 \pm 4.9$ years) (Table 1$)$.
Among adults, 51\% were women and among children, $63.6 \%$ were boys. The mean age at onset was $36.6 \pm 11.5$ years in women, $35.8 \pm 13.7$ years in men, $12.1 \pm 3.4$ years in girls, and $12.9 \pm 2.8$ years in boys. The majority $(60.2 \%)$ were in a low socioeconomic status. About one-fifth $(19.1 \%)$ of patients were illiterate. All the children were going to school at the time of inclusion in the study. In $66(90.4 \%)$ patients, the referral diagnosis was an organic neurological disorder; in only seven $(9.5 \%)$ patients, the referral diagnosis was PMD.

\section{Onset of Symptoms}

In our study, the onset of symptoms was arbitrarily classified as "abrupt" when the onset to peak disability was within a few days, "subacute" when it was over a few weeks, and "gradual" if it was over months (Table 1). The onset of the symptom was abrupt in $61.6 \%$; the rest had a either a gradual course $(32.9 \%)$ or subacute evolution (5.5\%). In comparison to men, women had a shorter duration of illness $(682.5 \pm 939.7$ days vs $412.8 \pm 694$ days, $p=0.65)$. In children, the mean duration of illness was almost similar in girls $(257 \pm 417.5$ days $)$ and boys (210.4 \pm 378.5 days). Abrupt onset of symptoms was more often seen in children compared with adults $(77.3 \% 54.9 \%, \mathrm{p}=0.28)$.

\section{Antecedent Illness}

An antecedent illness was identified in $34.2 \%$ of patients, of which fever was most common (10.9\%) (Table 1). Seizure was seen in $7.8 \%$ of adults and $13.6 \%$ of children. Headache was seen in adults $(7.8 \%)$, whereas abdominal pain was more common in children $(9 \%)$.

\section{Precipitating Factors}

Precipitating factors could be identified in $47.9 \%$ of the patients and included family stressors $(15 \%)$, stressors at school $(12.3 \%)$, marital disharmony $(6.8 \%)$, deaths in family $(5.5 \%)$, seizures $(5.5 \%)$, job dissatisfaction $(1.3 \%)$, and combined family stress-marital disharmony in $1.3 \%$ (Table 1). Family stressors were more frequent in adults $(19.6 \%)$, whereas stressors at school were frequent in children $(36.4 \%)$.

\section{Topographic Distribution}

The initial body part most often affected was the right upper limb $(30.1 \%)$, followed by head and neck (16.4\%) (Table 2). The right upper limb was involved in $29.4 \%$ of adults ( $31.8 \%$ women; $32 \%$ men) and $31.8 \%$ in children (37.5\% girls; $28.6 \%$ boys). Head and neck involvement was more common in adults $(21.6 \%)$ than in children $(21.6 \%$ vs $4.5 \%, \mathrm{p}=0.07)$. The other body parts initially involved are mentioned in Table 2.

\section{Clinical Phenomenology of PMD}

In the whole group, about $56.2 \%$ of patients had a pure PMD phenomenology, which consisted of tremors $(24.5 \%)$ as the most common symptom (Table 2). The other pure PMD phenomenology included myoclonus $(17.8 \%)$, dystonia $(6.8 \%)$, facial dystonia $(6.8 \%)$, and parkinsonism $(1.3 \%)$. In the remaining $43.8 \%$ of patients, a mixed pattern of PMD was seen. In this group, there were some patients whose movements could not be classified into any known phenomenology, such as bizarre limb 
movements $(5.5 \%)$, abnormal head movements (4.1\%), bizarre gait $(4.1 \%)$, and abnormal facial movements (4.1\%).

Tremor was observed in $31.4 \%$ of adults and $9 \%$ of children $(\mathrm{p}=0.04)$, whereas myoclonus was more common in children $(36.4 \%)$ than in adults $(9.8 \%)(p=0.006)$. Dystonia was observed in five patients and none had fixed dystonia. Speech abnormality in the form of mutism (absent verbalization and vocalization, with normal comprehension, reading, and writing) was seen only in adults (7.8\%). Abnormal facial movements were more frequently observed in children $(4.5 \%)$ than adults (3.9\%). Choreiform movement was seen in one girl. Mixed phenomenology was more often a feature in children $(31.8 \%)$. A combination of tremor and myoclonus was seen in $13.6 \%$ children and $3.9 \%$ adults and a combination of tremor and dystonia was seen in $9 \%$ children and $3.9 \%$ adults $(\mathrm{p}=0.13)$.

Tremors were more often seen in women $(42.3 \%)$ than in men $(20 \%)$ and more often in girls $(12.5 \%)$ than in boys $(7.1 \%)$. In children, myoclonus was almost equally prevalent in girls
(37.5\%) and boys (35.7\%), whereas in the adults it was only seen in women (19.2\%). Further details are given in Table 3.

\section{Clinical Clues}

Of the 73 patients, distractibility and variability was seen in $65.7 \%$, entrainability in $53.4 \%$, and suggestibility in $49.3 \%$ (Table 1). These features were more easily demonstrable in children than adults.

\section{Associated Psychiatric Comorbidities}

Associated psychiatric comorbidity was observed in $20.5 \%$ ( $23.5 \%$ adults, $13.6 \%$ children) with depression being the most common seen only in adults $(15.7 \% ; 15.4 \%$ women and $16 \%$ men) (Table 3). Children had predominantly anxiety disorder $(4.5 \%)$ and attention deficit hyperactive disorder (4.5\%).

Table 1: Demographic characteristics, onset, duration, antecedent illness, and precipitating factors

\begin{tabular}{|c|c|c|c|c|c|c|c|}
\hline \multirow[b]{2}{*}{ Characteristics } & \multirow[b]{2}{*}{$\begin{array}{l}\text { Whole group } \\
\quad(n=73)\end{array}$} & \multirow[b]{2}{*}{$\begin{array}{l}\text { Adults } \\
(n=51)\end{array}$} & \multirow[b]{2}{*}{$\begin{array}{l}\text { Pediatrics } \\
(n=22)\end{array}$} & \multicolumn{2}{|c|}{ Adults } & \multicolumn{2}{|c|}{ Pediatrics } \\
\hline & & & & $\begin{array}{l}\text { Women } \\
(n=26)\end{array}$ & $\begin{array}{c}\text { Men } \\
(n=25)\end{array}$ & $\begin{array}{c}\text { Girls } \\
(n=8)\end{array}$ & $\begin{array}{c}\text { Boys } \\
(n=14)\end{array}$ \\
\hline Total patients & $73(100 \%)$ & $51(69.8 \%)$ & $22(30.1 \%)$ & $26(51 \%)$ & $25(49 \%)$ & $8(36.4 \%)$ & $14(63.6 \%)$ \\
\hline Female/male & $34 / 39(46.57 \% / 53.42 \%)$ & $26 / 25(51 \% / 49 \%)$ & $8 / 14(36.4 \% / 63.6 \%)$ & - & - & - & - \\
\hline \multicolumn{8}{|l|}{ Age at presentation } \\
\hline Range (years) & $8-65$ & $20-65$ & $8-18$ & $20-65$ & $20-65$ & $8-18$ & $8-17$ \\
\hline Mean \pm SD (years) & $29.12 \pm 15.1$ & $36.23 \pm 9.2$ & $12.63 \pm 4.95$ & $36.6 \pm 11.5$ & $35.8 \pm 13.7$ & $12.1 \pm 3.4$ & $12.9 \pm 2.8$ \\
\hline \multicolumn{8}{|l|}{ Onset of illness } \\
\hline Abrupt & $45(61.6 \%)$ & $28(54.9 \%)$ & $17(77.3 \%)$ & $14(53.8 \%)$ & $14(56 \%)$ & $7(87.5 \%)$ & $10(71.4 \%)$ \\
\hline Subacute & $4(5.5 \%)$ & $1(2 \%)$ & $3(13.6 \%)$ & $1(3.8 \%)$ & 0 & $1(12.5 \%)$ & $2(14.3 \%)$ \\
\hline Gradual & $24(32.9 \%)$ & $22(43.1 \%)$ & $2(9 \%)$ & $11(42.3 \%)$ & $11(44 \%)$ & 0 & $2(14.3 \%)$ \\
\hline Mean duration of illness (days) & $449.2 \pm 42.4$ & $544.9 \pm 62.9$ & $227.3 \pm 15.6$ & $412.8 \pm 694$ & $682.5 \pm 939.7$ & $257 \pm 417.5$ & $210.4 \pm 378.5$ \\
\hline \multicolumn{8}{|l|}{ Antecedent illness } \\
\hline Fever & $8(10.9 \%)$ & $4(7.8 \%)$ & $4(18.2 \%)^{*}$ & $4(15.4 \%)$ & 0 & $2(25 \%)$ & $2(14.3 \%)$ \\
\hline Seizures & $7(9.6 \%)$ & $4(7.8 \%)$ & $3(13.6 \%)$ & $4(15.4 \%)$ & 0 & $3(37.5 \%)$ & 0 \\
\hline Headache & $4(5.5 \%)$ & $4(7.8 \%)$ & 0 & $2(7.7 \%)$ & $2(8 \%)$ & 0 & 0 \\
\hline Joint pain & $3(4.1 \%)$ & $2(3.9 \%)$ & $1(4.5 \%)$ & $1(3.8 \%)$ & $1(4 \%)$ & 0 & $1(7.1 \%)$ \\
\hline Abdominal pain & $3(4.1 \%)$ & $1(2 \%)$ & $2(9 \%)$ & 0 & $1(4 \%)$ & $1(12.5 \%)$ & $1(7.1 \%)$ \\
\hline Trauma & $2(2.7 \%)$ & $1(2 \%)$ & $1(4.5 \%)$ & $1(3.8 \%)$ & 0 & $1(12.5 \%)$ & 0 \\
\hline Giddiness & $1(1.3 \%)$ & $1(2 \%)$ & 0 & 0 & $1(4 \%)$ & 0 & 0 \\
\hline Headache with conjunctivitis & $1(1.3 \%)$ & 0 & $1(4.5 \%)$ & 0 & 0 & 0 & $1(7.1 \%)$ \\
\hline \multicolumn{8}{|l|}{ Precipitating factors } \\
\hline Family stressors & $11(15 \%)$ & $10(19.6 \%)$ & $1(4.5 \%) \mathrm{d}$ & $4(15.4 \%)$ & $6(24 \%)$ & $1(12.5 \%)$ & 0 \\
\hline Marital disharmony & $5(6.8 \%)$ & $5(9.8 \%)$ & 0 & $4(15.4 \%)$ & $1(4 \%)$ & - & - \\
\hline Deaths in family & $4(5.5 \%)$ & $3(5.9 \%)$ & $1(4.5 \%)$ & $3(11.5 \%)$ & - & 0 & $1(7.1 \%)$ \\
\hline Family and marital issues & $1(1.3 \%)$ & $1(2 \%)$ & 0 & $1(3.8 \%)$ & - & - & - \\
\hline School or college stressors & $9(12.3 \%)$ & $1(2 \%)$ & $8(36.4 \%)$ & - & $1(4 \%)$ & $3(37.5 \%)$ & $5(35.7 \%)$ \\
\hline Job dissatisfaction & $1(1.3 \%)$ & $1(2 \%)$ & 0 & - & $1(4 \%)$ & - & - \\
\hline
\end{tabular}

Comparison of adults and pediatric patients: p values: $* 0.04, \Phi[0.01$. 
Table 2: Initial body part involved, clinical phenomenology and clinical clues

\begin{tabular}{|c|c|c|c|c|c|c|c|}
\hline \multirow[b]{2}{*}{ Characteristics } & \multirow[b]{2}{*}{$\begin{array}{l}\text { Whole group } \\
\quad(\mathbf{N}=73)\end{array}$} & \multirow[b]{2}{*}{$\begin{array}{c}\text { Adults } \\
(\mathbf{n}=\mathbf{5 1})\end{array}$} & \multirow[b]{2}{*}{$\begin{array}{c}\text { Pediatrics } \\
(\mathbf{n}=\mathbf{2 2})\end{array}$} & \multicolumn{2}{|c|}{ Adults } & \multicolumn{2}{|c|}{ Pediatrics } \\
\hline & & & & $\begin{array}{l}\text { Women } \\
(\mathbf{n}=\mathbf{2 6})\end{array}$ & $\begin{array}{c}\text { Men } \\
(\mathbf{n}=\mathbf{2 5})\end{array}$ & $\begin{array}{l}\text { Girls } \\
(\mathrm{n}=8)\end{array}$ & $\begin{array}{c}\text { Boys } \\
(n=14)\end{array}$ \\
\hline \multicolumn{8}{|l|}{ Body part affected first } \\
\hline Right UL & $22(30.1 \%)$ & $15(29.4 \%)$ & $7(31.8 \%)$ & $7(31.8 \%)$ & $8(32 \%)$ & $3(37.5 \%)$ & $4(28.6 \%)$ \\
\hline Head and neck & $12(16.4 \%)$ & $11(21.6 \%)$ & $1(4.5 \%)$ & $7(31.8 \%)$ & $4(16 \%)$ & 0 & $1(7.1 \%)$ \\
\hline Both LL & $9(12.3 \%)$ & $7(13.7 \%)$ & $2(9 \%)$ & $4(15.4 \%)$ & $3(12 \%)$ & $1(12.5 \%)$ & $1(7.1 \%)$ \\
\hline $\mathrm{B} / \mathrm{L} \mathrm{UL}$ & $6(8.2 \%)$ & $2(3.9 \%)$ & $4(18.2 \%)$ & $2(7.7 \%)$ & 0 & $1(12.5 \%)$ & $3(21.4 \%)$ \\
\hline Left UL & $5(6.8 \%)$ & $3(5.9 \%)$ & $2(9 \%)$ & $1(3.8 \%)$ & $2(8 \%)$ & $1(12.5 \%)$ & $1(7.1 \%)$ \\
\hline Speech & $4(5.5 \%)$ & $4(7.8 \%)$ & 0 & 0 & $4(16 \%)$ & 0 & 0 \\
\hline Eyes & $3(4.1 \%)$ & $2(3.9 \%)$ & $1(4.5 \%)$ & $1(3.8 \%)$ & $1(4 \%)$ & 0 & $1(7.1 \%)$ \\
\hline Face & $3(4.1 \%)$ & $1(2 \%)$ & $2(9 \%)$ & $1(3.8 \%)$ & 0 & $1(12.5 \%)$ & $1(7.1 \%)$ \\
\hline Right LL & $3(4.1 \%)$ & $2(3.9 \%)$ & $1(4.5 \%)$ & $1(3.8 \%)$ & $1(4 \%)$ & 0 & $1(7.1 \%)$ \\
\hline Left LL & $2(2.7 \%)$ & $1(2 \%)$ & $1(4.5 \%)$ & $1(3.8 \%)$ & 0 & 0 & $1(7.1 \%)$ \\
\hline Right UL and LL & $2(2.7 \%)$ & $1(2 \%)$ & $1(4.5 \%)$ & 0 & $1(4 \%)$ & $1(12.5 \%)$ & 0 \\
\hline Left UL and LL & $1(1.3 \%)$ & $1(2 \%)$ & 0 & $1(3.8 \%)$ & $1(4 \%)$ & 0 & 0 \\
\hline Palatal & $1(1.3 \%)$ & $1(2 \%)$ & 0 & $1(3.8 \%)$ & 0 & 0 & 0 \\
\hline \multicolumn{8}{|l|}{ Types of PMD } \\
\hline Tremors & $18(24.5 \%)$ & $16(31.4 \%)$ & $2(9 \%)^{*}$ & $11(42.3 \%)$ & $5(20 \%)$ & $1(12.5 \%)$ & $1(7.1 \%)$ \\
\hline Myoclonus & $13(17.8 \%)$ & $5(9.8 \%)$ & $8(36.4 \%) \pi[$ & $5(19.2 \%)$ & 0 & $3(37.5 \%)$ & $5(35.7 \%)$ \\
\hline Tremor + myoclonus & $5(6.8 \%)$ & $2(3.9 \%)$ & $3(13.6 \%)$ & $1(3.8 \%)$ & $1(4 \%)$ & $2(25 \%)$ & $1(7.1 \%)$ \\
\hline Bizarre limb movements & $4(5.5 \%)$ & $3(5.9 \%)$ & $1(4.5 \%)$ & $2(7.7 \%)$ & $1(4 \%)$ & 0 & $1(7.1 \%)$ \\
\hline Tremor + dystonia & $4(5.5 \%)$ & $2(3.9 \%)$ & $2(9 \%)$ & 0 & $2(8 \%)$ & 0 & $2(14.3 \%)$ \\
\hline Dystonia & $5(6.8 \%)$ & $4(7.8 \%)$ & $1(4.5 \%)$ & $1(3.8 \%)$ & $312 \%)$ & 0 & $1(7.1 \%)$ \\
\hline Gait abnormality & $3(4.1 \%)$ & $2(3.9 \%)$ & $1(4.5 \%)$ & 0 & $2(8 \%)$ & 0 & $1(7.1 \%)$ \\
\hline Abnormal head movements & $3(4.1 \%)$ & $3(5.9 \%)$ & 0 & $2(7.7 \%)$ & $1(4 \%)$ & 0 & 0 \\
\hline Facial dystonia & $5(6.8 \%)$ & $3(5.9 \%)$ & $2(9 \%)$ & $2(7.7 \%)$ & $1(4 \%)$ & 0 & $2(14.3 \%)$ \\
\hline Facial dystonia + mutism & $2(2.7 \%)$ & $2(3.9 \%)$ & 0 & 0 & $2(8 \%)$ & 0 & 0 \\
\hline Mutism + gait abnormality & $2(2.7 \%)$ & $2(3.9 \%)$ & 0 & 0 & $2(8 \%)$ & 0 & 0 \\
\hline Abnormal head movements + tremors & $2(2.7 \%)$ & $2(3.9 \%)$ & 0 & 0 & $2(8 \%)$ & 0 & 0 \\
\hline Abnormal facial movements & $3(4.1 \%)$ & $2(3.9 \%)$ & $1(4.5 \%)$ & $1(3.8 \%)$ & 0 & $1(12.5 \%)$ & 0 \\
\hline Parkinsonism & $1(1.3 \%)$ & $1(2 \%)$ & 0 & 0 & $1(4 \%)$ & 0 & 0 \\
\hline Facial dystonia + tremors & $1(1.3 \%)$ & $1(2 \%)$ & 0 & 0 & $1(4 \%)$ & 0 & 0 \\
\hline Choreiform + dystonia & $1(1.3 \%)$ & 0 & $1(4.5 \%)$ & 0 & 0 & $1(12.5 \%)$ & 0 \\
\hline $\begin{array}{l}\text { Palatal myoclonus }+ \text { astasia abasia }+ \text { facial } \\
\text { dystonia* }\end{array}$ & $1(1.3 \%)$ & $1(2 \%)$ & 0 & $1(3.8 \%)$ & 0 & 0 & 0 \\
\hline \multicolumn{8}{|l|}{ Clinical clues } \\
\hline Distractibility & $48(65.7 \%)$ & $33(64.7 \%)$ & $15(68.1 \%)$ & $19(73 \%)$ & $14(56 \%)$ & $7(87.5 \%)$ & $8(57.1 \%)$ \\
\hline Entrainability & $39(53.4 \%)$ & $24(47 \%)$ & $15(68.1 \%)$ & $16(61.5 \%)$ & $8(32 \%)$ & $7(87.5 \%)$ & $8(57.1 \%)$ \\
\hline Suggestibility & $36(49.3 \%)$ & $23(45.1 \%)$ & $13(59.1 \%)$ & $15(57.7 \%)$ & $8(32 \%)$ & $6(24 \%)$ & $7(50 \%)$ \\
\hline Variability & $48(65.7 \%)$ & $31(60.8 \%)$ & $17(77.3 \%)$ & $18(69.2 \%)$ & $13(52 \%)$ & $8(100 \%)$ & $9(64.3 \%)$ \\
\hline Miscellaneous (induction by tuning fork ) & $1(1.3 \%)$ & $1(2 \%)$ & 0 & $1(3.8 \%)$ & 0 & 0 & 0 \\
\hline
\end{tabular}

Comparison of adults and pediatric patients: p values: *0.04, $\mathscr{T} 0.006$.

$\mathrm{B} / \mathrm{L}=$ bilateral, $\mathrm{LL}=$ lower limb, $\mathrm{UL}=$ upper limb.

*The status of palatal myoclonus, whether functional or organic, was not certain. 
Table 3: Inpatient care, associated psychiatric comorbidity, electrophysiological tests, therapy, and outcome

\begin{tabular}{|c|c|c|c|c|c|c|c|}
\hline \multirow[b]{2}{*}{ Characteristic } & \multirow[b]{2}{*}{ Whole group $(\mathrm{N}=73)$} & \multirow[b]{2}{*}{ Adults $(\mathrm{n}=\mathbf{5 1})$} & \multirow[b]{2}{*}{ Pediatrics $(n=22)$} & \multicolumn{2}{|c|}{ Adults } & \multicolumn{2}{|c|}{ Pediatrics } \\
\hline & & & & Women $(n=26)$ & $\operatorname{Men}(\mathbf{n}=25)$ & Girls $(n=8)$ & $\begin{array}{c}\text { Boys } \\
(n=14)\end{array}$ \\
\hline Inpatient care & $31(42.5 \%)$ & $21(41.2 \%)$ & $10(45.45 \%)$ & $10(38.5 \%)$ & $11(44 \%)$ & $4(50 \%)$ & $6(42.8 \%)$ \\
\hline \multicolumn{8}{|l|}{ Associated psychiatric comorbidity } \\
\hline Depression & $8(10.9 \%)$ & $8(15.7 \%)$ & 0 & $4(15.4 \%)$ & $4(16 \%)$ & 0 & 0 \\
\hline Personality disorder & $2(2.7 \%)$ & $2(3.9 \%)$ & 0 & 0 & $2(8 \%)$ & 0 & 0 \\
\hline Dysthymia & $1(1.3 \%)$ & $1(2 \%)$ & 0 & $1(3.8 \%)$ & 0 & 0 & 0 \\
\hline Anxiety disorder & $1(1.3 \%)$ & 0 & $1(4.5 \%)$ & 0 & 0 & 0 & $1(7.1 \%)$ \\
\hline ADHD & $1(1.3 \%)$ & 0 & $1(4.5 \%)$ & 0 & 0 & $1(12.5 \%)$ & 0 \\
\hline Electrophysiological tests (confirmed/total done) & $\begin{array}{c}17 / 3 \\
28.7 \%(\mathrm{n}=21)\end{array}$ & $\begin{array}{c}12 / 15 \\
80 \%(\mathrm{n}=15)\end{array}$ & $\begin{array}{c}5 / 6 \\
83.3 \%(\mathrm{n}=6)\end{array}$ & $\begin{array}{c}8 / 8 \\
100 \%(\mathrm{n}=8)\end{array}$ & $\begin{array}{l}4 / 7 \\
57.1 \%(\mathrm{n}=7)\end{array}$ & $\begin{array}{l}2 / 2 \\
100 \%(\mathrm{n}=2)\end{array}$ & $\begin{array}{l}3 / 4 \\
75 \%(n=4)\end{array}$ \\
\hline \multicolumn{8}{|l|}{ Placebo effect } \\
\hline Placebo given & $18(100 \%)$ & $11(100 \%)$ & $7(100 \%)$ & $10(100 \%)$ & $1(100 \%)$ & $3(100 \%)$ & $4(100 \%)$ \\
\hline Placebo effect & $17(94.4 \%)$ & $10(90.9 \%)$ & $7(100 \%)$ & $10(100 \%)$ & 0 & $3(100 \%)$ & $4(100 \%)$ \\
\hline Placebo failure & $1(0.6 \%)$ & $1(9.1 \%)$ & 0 & 0 & $1(100 \%)$ & 0 & 0 \\
\hline \multicolumn{8}{|l|}{ Outcome } \\
\hline Improved & $42(57.5 \%)$ & $25(49 \%)$ & $17(77.3 \%)$ & $15(57.7 \%)$ & $10(40 \%)$ & $6(24 \%)$ & $11(78.6 \%)$ \\
\hline No improvement & $19(26 \%)$ & $16(31.4 \%)$ & $3(13.6 \%)$ & $6(23 \%)$ & $10(40 \%)$ & $1(12.5 \%)$ & $2(14.3 \%)$ \\
\hline Lost to follow- up & $12(16.4 \%)$ & $10(19.6 \%)$ & $2(9 \%)$ & $5(19.2 \%)$ & $5(20 \%)$ & $1(12.5 \%)$ & $1(7.1 \%)$ \\
\hline
\end{tabular}

$\mathrm{ADHD}=$ attention deficit hyperactivity disorder. 
Table 4: Comparison of duration of illness with the outcome

\begin{tabular}{l|c|c|c|c}
\hline & \multicolumn{3}{|c}{ Outcome } \\
\hline & \multicolumn{2}{|c|}{ Adults } & \multicolumn{3}{|c}{ Children } \\
\hline & Improved & Not improved & $17(85 \%)$ & $3(15 \%)$ \\
\hline Number of patients* $(\%)$ & $25(60.9 \%)$ & $16(39.1 \%)$ & $67.8 \pm 57.7$ & $365.5 \pm 57.9$ \\
\hline Duration of illness & $374.2 \pm 62.9$ & $587.2 \pm 120.2$ & 0.03 & \\
\hline$p$ value & 0.35 & & & \\
\hline
\end{tabular}

*Among those who came for follow-up (adults $=41$, children $=20$ ).

\section{Associated Neurological Illness}

In our study, seizures (13.6\% children and $7.8 \%$ adults), tic disorder ( $4.5 \%$ children and $2 \%$ adults), and palatal myoclonus ( $2 \%$ adults) were the only associated neurological illnesses. However, these could also have been psychogenic.

\section{Electrophysiological Tests}

The electrophysiological tests consisted of a multichannel recording of surface electromyelogram (EMG), somatosensory evoked potentials, premovement potentials, and electroencephalography, depending on the type of movement (Table 3). These tests were done in $28.7 \%$ of patients $(27.3 \%$ children, $29.4 \%$ adults). Tremor recording was done using multichannel surface EMG recording and observed for variability, entrainability, suggestibility, and distractability. Conclusive results were obtained in five of six children (100\% girls, $75 \%$ boys) and 12 of 15 adults (100\% women, $57.1 \%$ men). Most often, the conclusive results were from surface EMG, which showed variability, entrainability, suggestibility, and distractability.

\section{Treatment and Outcome Measures}

Inpatient care was given to $42.5 \%$ of patients; the rest were evaluated and treated on an outpatient basis (Tables 3 and 4). All patients were evaluated by a psychiatrist after the neurologist established a diagnosis of PMD. While communicating the diagnosis of PMD, a detailed description of the illness was provided rather than using terms such as "functional" or "psychogenic." The patients and their caregivers were interviewed separately and later together to explain the nature of illness. The patients were taught that the movements were beyond their controland have their origin in the brain, but there are no structural abnormalities of the brain. These abnormal movements may be a manifestation of underlying stress and can be improved with behavioral therapy or counseling.

Patients received treatment in the form of counseling, family therapy, behavioral therapy, or pharmacological therapy as required. Eight patients were treated with antidepressants and five with behavioral therapy. No one received physiotherapy or botulinum toxin injections.

Placebo therapy was given to $21.6 \%$ of adults, $37.5 \%$ of girls, and $28.6 \%$ of boys after obtaining informed consent from the patient or legal guardian. Placebo response (that often resulted in therapy) was primarily used to establish the diagnosis of PMD (improvement or total cessation of abnormal movement) in only those patients in which we were unable to clinically establish a diagnosis of PMD by the usual criteria of distractibility, variability, entrainability, etc. The most common placebo used was placing of a vibrating tuning fork over the forehead or another part of body (most often the body part involved based on patient's history) with strong suggestion. A 0.1-ml normal saline subcutaneous injection was used only in two patients who did not respond to tuning fork stimulation, but in whom PMD was strongly suspected. In both of these patients (both young girls), the placebo effect was very satisfactory with total cessation of PMD. It was not used for chronic treatment and there was no fixed time interval of placebo administration. Placebo was administered to 18 patients. The phenomenology in these patients included nine patients with myoclonus (five adults and four children), three adults with tremors, four patients with facial dystonia (two adults and two children), one child with tremor and dystonia, and one adult with gait abnormality. All these patients, except one adult with myoclonus, responded to placebo therapy.

Improvement with placebo was observed in approximately $94.4 \%$ of patients. Placebo effect was more readily observed in children $(100 \%)$ than in adults $(90.9 \%)(p=0.26)$. The adult patient who failed to improve with placebo subsequently responded to counseling and behavioral therapy. Placebo benefit was more readily observed in patients whose duration of illness was days to months than those with duration of illness in years. The mean duration of illness in adults was $544.9 \pm 62.9$ days and the placebo effect was $90.9 \%$, whereas in children the mean duration was $227.3 \pm 15.6$ days with placebo effect of $100 \%$.

Approximately $19.6 \%$ of adults and $9 \%$ of children $(12.5 \%$ girls; $7.1 \%$ boys) were lost to follow-up. Almost a similar number of men and women were lost to follow-up. Among those who came for follow-up, although an overall good outcome was observed in $57.5 \%$, the outcome was better in children $(77.3 \%$ ) compared with adults $(49.0 \%)$. The number of adults and children who came for follow-up was $41(80.3 \%)$ and 20 (90.9\%), respectively. The mean duration of illness in the adults who improved $(60.9 \%)$ was lower than those $(39.1 \%)$ who did not improve $(374.2 \pm 62.9$ days vs $587.2 \pm 120.2$ days, $\mathrm{p}=0.35)$. Similarly, those children who had improvement at follow-up $(85 \%)$ had a significantly shorter mean duration of illness compared with those children $(15 \%)$ who did not improve $(67.8 \pm 57.7$ days vs $365.5 \pm 57.9, \mathrm{p}=0.03)$.

\section{DISCUSSION}

PMD poses a great diagnostic challenge and needs the expertise of both a neurologist and a psychiatrist. ${ }^{2}$ Patients who are referred to any tertiary care center with a possible diagnosis of 
PMD probably represent the tip of iceberg with a very large proportion of patients in the community undiagnosed. In only seven (9.5\%) patients, the referral diagnosis was PMD. This suggests that there is a lack of awareness of PMD among physicians. The social stigma associated with a diagnosis of PMD, refusal of patients as well as the caregivers to accept a diagnosis of so called "functional" disorder, and lack of enthusiasm among most neurologists as well as psychiatrists to manage and follow-up on these patients might contribute to the low prevalence observed, especially from this part of the continent.

The prevalence of psychogenic neurological disorders have been reported to be $1 \%$ to $9 \%$ among patients attending neurology clinics $^{8,9}$ and those attending specialty clinics of movement disorders, the prevalence has been reported to vary from $2 \%$ to $20 \%{ }^{1,6,10}$ There are no studies reported from Asia.

In this study, we have only reported PMD that were seen by one movement disorder specialist over 14 years. There are many patients with PMD who are underdiagnosed, or may have attended the large psychiatry department in our hospital (about three times larger than neurology), including adult and child psychiatry. Some patients with PMD have been referred to us by our psychiatry department, but this may not represent the actual burden of PMD. On an average, these patients have consulted two to three physicians before being seen at our hospital. Most patients were referred by the primary care physicians. In India, there is social stigma associated with anything "psychogenic" or "psychiatric"; therefore, many patients may not have opted for any medical consultation. As a result, the current study does not provide any information about the prevalence of PMD at our center or in India.

\section{An Overview of PMD in Adults}

In our study, the age of onset ranged from 20 to 65 years, with the mean age of onset of illness being $36.2 \pm 9.2$ years, comparable to other studies. ${ }^{5,10-12}$ This wide variability of age suggests that PMD can occur at any age group, depending on the psychosocial and cultural factors present in different phases of life. Our cohort of patients predominantly belonged to lower and middle socioeconomic status, which could have influenced the results of our study. The majority of patients were seen by primary care physicians, and our institute being a tertiary referral center, there could have been a referral bias.

Studies have shown abrupt onset of illness in $73 \%$ to $83 \%$ of patients, which is similar to our study of $54.9 \%$ in adults. ${ }^{10,11,13,14}$ Abrupt onset was seen in $54 \%$ in a previous study on PMD. ${ }^{10}$ Abrupt onset with fluctuating symptoms and spontaneous remission are features of PMD.

Our study identified antecedent illness in $34.2 \%$ and precipitating factors in $47.9 \%$ patients. Various studies have reported precipitating factors ranging from $51 \%$ to $83.7 \% .^{11,12}$ Other precipitating factors that have been reported to precede PMD include death of a relative, marital problems, poverty, unemployment, domestic violence, history of exposure to a disease model, caring for the chronically ill, work related, personal life stressors, and others. ${ }^{10,13,14}$ In one study, PMD patients reported a history of emotional abuse and physical neglect, higher rates of total childhood trauma, greater fear associated with traumatic events, and a greater number of traumatic episodes. ${ }^{15,16}$ To our knowledge, antecedent illness has not been described in previous studies.
The topographical distribution in our patients is in accordance with prior observation by Deuschl, in which the right hand was involved in $84 \%$ of cases. ${ }^{17}$ Similar to our study, tremor was the most common PMD observed by many other authors. ${ }^{10,12,13,18-20}$ Others have reported dystonia as the most common manifestation. ${ }^{21}$ Psychogenic facial movements, with blepharospasm and spasm of platysma, with or without dystonia, is also described. ${ }^{14}$ In a study of 14 patients of psychogenic parkinsonism, patients presented with tremors, bradykinesia, voluntary rigidity, and abnormal bizarre response to postural testing. ${ }^{22}$ The prevalence of psychogenic parkinsonism is very low about $0.17 \%$ to $0.5 \%$. $^{10,22}$ We had one case of psychogenic parkinsonism who presented with tremors and bradykinesia.

It is a matter of speculation why certain types of movement disorders manifest more commonly as psychogenic. Often, there is a change from one phenomenology to another over time, and mixed types are also common. These varying movements do not conform to any known phenomenology and do not have an organic basis. Williams and colleagues found that $79 \%$ of patients had multiple types and only $21 \%$ had a single definable type. ${ }^{23}$

Distractibility (96.4\%) is more commonly observed in PMD. ${ }^{10}$ Other studies have observed entrainability, suggestibility, and variability predominantly in psychogenic tremors but in varying degrees. $^{11,12}$ These specific tests aid in differentiating organic from PMD and should always be performed in suspected cases.

Depression was the most common psychiatric illness observed in our study with predominance in women. However the prevalence was far less when compared to other studies. ${ }^{10-14}$ Others have found somatoform disorders as the predominant psychiatric illness. ${ }^{20,21}$ Point and life time prevalence rates for psychiatric illness have also been determined. ${ }^{24}$ The lower prevalence of psychiatric comorbidities in our series could be due to social stigma and poor follow-up. It is possible that patients with PMD have significant psychosocial stressors at home or workplace that leads to depression as the most common associated psychiatric comorbidity.

It is not uncommon to find PMD in patients with neurological disorders. Repeated observations and unresponsiveness to medications may help differentiate between the two. In our study, seizures, tic disorders, and palatal myoclonus was the associated neurological illness. Associated neurological illness has been identified in other studies. ${ }^{5,10,13,25,26}$ Research in cognitive neuroscience has tried to explain the relation between organic movement disorder and PMD. There exist various circuits in the brain that give a sense of intention to movement that are disrupted in organic neurological disorder. Functional imaging studies have shown a strong association between the amygdala, supplementary motor area, and prefrontal cortex, suggesting that emotional stimuli influences these areas and culminates in the generation of movement. ${ }^{27}$

Patients with PMD are less likely to accept a psychological basis of their symptoms and are prone to consult multiple doctors. Therefore, follow-up of these patients, even in the best hospitals, is dismal and difficult to treat. Response rates in other studies were found to be $4.5 \%$ to $57 \% .{ }^{10-13,20}$ Patients with a short duration of illness had better outcomes, which was also observed in our study. ${ }^{8,24}$ PMD may become chronic because of delayed medical attention, being treated as a neurological disorder for a long duration, coexisting neurological disorders, or social and cultural community factors. The outcome depends on age, onset, and 


\section{Table 5: Comparison of various studies with present study}

\begin{tabular}{|c|c|c|c|c|c|c|}
\hline Author & Place of study & Sample size & Age distribution & $\begin{array}{l}\text { Gender } \\
\text { distribution }\end{array}$ & Phenomenology observed & Associated psychiatric comorbidities \\
\hline Shill et al ${ }^{14}$ & United States & $29 \mathrm{PMD}$ and 50 controls & Median age, 50 years & $90 \%$ women & $\begin{array}{l}\text { Tremor (55\%), myoclonus (28\%), dystonia } \\
\text { (17\%), Parkinsonism (17\%), gait } \\
\text { disturbance }(10 \%)\end{array}$ & $30 \%$ \\
\hline Ertan et $^{12}{ }^{12}$ & Turkey & 49 PMD cases & $\begin{array}{l}\text { Mean age of } 36.9 \pm 15.9 \text { in adults; } \\
9.2 \pm 2.2 \text { in children }\end{array}$ & $\begin{array}{l}69.4 \% \text { were women; } \\
8.16 \% \text { were } \\
\text { children }\end{array}$ & $\begin{array}{l}\text { Of the } 1743 \text { patients, } 49 \text { (2.8\%) had PMD. } \\
\text { Tremor }(44.8 \%) \text {, dystonia (24.4\%), gait } \\
\text { disorder (12.3\%), Parkinsonism }(8.2 \%) \\
\text { chorea/ballism }(6.1 \%) \text {, tics }(4 \%)\end{array}$ & $\begin{array}{l}53 \% \text { (32.6\%) major depression, } 16.3 \% \\
\text { anxiety disorder, } 4 \% \text { residual } \\
\text { schizophrenia. } 89.8 \% \text { conversion } \\
\text { disorder, } 8.2 \% \text { malingering, } 2 \% \\
\text { factitious disorder) }\end{array}$ \\
\hline Schwingenschuh et al ${ }^{29}$ & United Kingdom & 15 children & Mean age of onset $12.3 \pm 2.6$ years & $80 \%$ were girls & $\begin{array}{l}\text { Dystonia }(47 \%) \text {, tremor }(40 \%) \text {, gait } \\
\text { disorders }(13 \%)\end{array}$ & - \\
\hline Williams et $\mathrm{al}^{23}$ & United States & 152 adult patients & Mean age of onset 36.9 years & $87 \%$ were females & $\begin{array}{l}\text { Dystonia (62\%), tremor (16\%), gait } \\
\text { disorder }(11 \%) \text {, and myoclonus }(8 \%)\end{array}$ & $\begin{array}{l}\text { Dysthymia, adjustment disorder, } \\
\text { depression, oppositional defiant } \\
\text { disorder, BPAD, OCD. }\end{array}$ \\
\hline Factor et al ${ }^{10}$ & United States & 28 PMD cases & Mean age of 50 years & $61 \%$ were women & $\begin{array}{l}\text { Of the } 842 \text { consecutive patients, } 28 \text { (3.3\%) } \\
\text { were PMD. Tremor (50\%), dystonia } \\
\text { (18\%), myoclonus (14\%), Parkinsonism } \\
\text { (7\%), tremor + dystonia (3.5\%), } \\
\text { unclassifiable foot and toe movements } \\
(3.5 \%)\end{array}$ & $\begin{array}{l}\text { 50\%. (32.1\% depression, } 17.9 \% \text { alcohol } \\
\text { dependance } 10.7 \% \text { anxiety, } 7.1 \% \text { PTSD, } \\
7.1 \% \text { schizophrenia ) }\end{array}$ \\
\hline Feinstein et $\mathrm{al}^{24}$ & Canada & 88 PMD cases & Mean age was 48.6 years & $62.7 \%$ were women & $\begin{array}{l}42 \text { patients had hyperkinetic PMD } \\
\text { (dystonia, tremor, myoclonus) }\end{array}$ & Mental illness was determined in $95.3 \%$ \\
\hline Munhoz et $\mathrm{al}^{20}$ & Brazil & 83 PMD cases & Mean age of onset of $39 \pm 5.1$ years & $\begin{array}{l}87.95 \% \text { were } \\
\text { women }\end{array}$ & $\begin{array}{l}\text { Tremor } 50.6 \% \text {, dystonia } 32.5 \% \text {, cerebellar- } \\
\quad \text { like ataxia } 4.16 \%\end{array}$ & $\begin{array}{l}\text { 80.7\%. Somatoform disorders } 69.9 \% \text {. } \\
\text { Mood disorders including major } \\
\text { depression and dysthymic disorder } \\
33.7 \% \text {. Anxiety disorders } 25.3 \% \\
\text { Personality disorders } 18.1 \% \text {. } \\
\text { Schizophrenia and bipolar type I } \\
\text { disorder } 2.4 \%\end{array}$ \\
\hline Ferrara et $\mathrm{al}^{28}$ & United States & 54 PMD children & Mean age $14.2 \pm 2.11$ years & $77.7 \%$ were girls & $\begin{array}{l}\text { Of } 1722 \text { children, } 3.1 \% \text { had PMD. Tremor } \\
65 \% \text {, dystonia } 43 \% \text {, myoclonus or jerks } \\
37 \% \text {, gait disorders } 22 \% \text {, spasm } 11 \% \text {, } \\
\text { speech } 7 \% \text {, athetosis and eyelid apraxia } \\
2 \% \text { each }\end{array}$ & $\begin{array}{l}52 \% \text {. Suicidal ideations } 9.1 \% \text {, perfectionist } \\
\text { personality 37\%, ADHD 9\%, learning } \\
\text { deficits 3.7\% }\end{array}$ \\
\hline Thomas et $\mathrm{al}^{13}$ & United States & 228 PMD cases & Mean age was $42.3 \pm 14.3$ years & $72.8 \%$ were women & $\begin{array}{l}\text { Of } 12,625 \text { patients } 4.7 \% \text { were PMD. } \\
\text { Tremor } 40.8 \% \text {, dystonia } 40.2 \% \text {, } \\
\text { myoclonus } 17.0 \% \text {, tics } 4.3 \% \text {, gait } \\
\text { disorder } 3.9 \% \text {, Parkinsonism } 3.1 \% \text {, } \\
\text { dyskinesial.4\%, chorea } 0.6 \% \text {, more than } \\
\text { one form of PMD } 7.3 \%\end{array}$ & Depression $51.8 \%$, anxiety $21.9 \%$ \\
\hline Canavese et $\mathrm{al}^{32}$ & Italy & 14 PMD children & Mean age of 11.5 years & 8 girls & Tremor (36\%) and dystonia (29\%) & $79 \%$ had organic movement disorders \\
\hline Fasano et al ${ }^{14}$ & Italy & $\begin{array}{l}61 \text { psychogenic facial } \\
\text { movements }\end{array}$ & Mean age of $37.0 \pm 11.3$ years & $91.8 \%$ were females & $\begin{array}{l}\text { Dystonia-like spasms involving lips } \\
(60.7 \%) \text {, eyelids }(50.8 \%) \text {, perinasal } \\
\text { region }(16.4 \%) \text {, forehead }(9.8 \%)\end{array}$ & $\begin{array}{l}\text { Depression (38\%), tension headache } \\
(26.4 \%)\end{array}$ \\
\hline${\text { Ganos et } \mathrm{al}^{21}}^{21}$ & United Kingdom & 26 PMD cases & Mean age of 38.6 years & $73 \%$ were women & $\begin{array}{l}\text { Dystonia most common. Mixed } \\
\text { phenomenology seen in } 69.2 \%\end{array}$ & $\begin{array}{l}\text { Psychiatric comorbidities in } 26.9 \% \text { and } \\
\text { coexisting organic movement disorder in } \\
19.2 \%\end{array}$ \\
\hline Faust et $\mathrm{al}^{31}$ & Canada & 13 PMD & Mean age of 13.1 years & 10 females & $\begin{array}{l}\text { Dystonia (5), tremor (3), chorea (3), } \\
\text { myoclonus (3) }\end{array}$ & $\begin{array}{l}\text { Psychiatric comorbidities in 77\% (anxiety, } \\
\text { obsessive compulsive disorder) }\end{array}$ \\
\hline Present study & India & 73 PMD cases & Mean age of $29.1 \pm 15.1$ years & $\begin{array}{l}51 \text { adults and } 22 \\
\text { children }\end{array}$ & $\begin{array}{l}\text { Tremor }(24.5 \%) \text {, myoclonus }(17.8 \%), \\
\text { dystonia }(6.8 \%)\end{array}$ & $\begin{array}{l}\text { Depression }(10.9 \%) \text {, personality disorder } \\
(2.7 \%)\end{array}$ \\
\hline
\end{tabular}


duration; underlying psychopathology; level of literacy; interventional methods; and family support.

In our study, there was no significant difference in the prevalence of PMD among men and women. Female predominance of $61 \%$ to $90 \%$ has been observed in many studies. ${ }^{10-12,18}$ The low prevalence of women in our study is probably from the usual practice of low referral of women in our country owing to low educational status, social stigma and misconceptions of the disease.

\section{An Overview of PMD in Children}

There is a paucity of literature on PMD in children. The prevalence of PMD in children is about $3.1 \%{ }^{28}$ The mean age of onset of symptoms have been reported to be $12.3 \pm 2.6-14.2 \pm 2.1$ (7.0-17.7) years. ${ }^{28,29}$ The mean age of onset of PMD in pediatric population in our study was $12.1 \pm 3.4$ (8-18) years, which is consistent with previous studies. In our series, boys outnumbered girls. This is perhaps an important observation, which suggests that there are probably various psychosocial factors starting from adolescence. $^{28}$

In a study of 15 cases, the most common type of PMD in children was dystonia (47\%) with eight patients having precipitating factor. ${ }^{29}$ Six patients showed complete improvement, and the majority had a short duration of illness. In a study of 54 children, $75 \%$ were girls, and sexual assault was observed in $6 \%$ and $50 \%$ had depression or anxiety. Tremor was observed in $65 \%$ followed by dystonia in $43 \%{ }^{28}$ Follow-up studies of pediatric conversion disorder reports remission rates were between $85 \%$ and $97 \%{ }^{30}$ Acute onset and short duration symptoms predict good response. ${ }^{8}$ A multidisciplinary approach with family support is essential in the management of PMD in children. ${ }^{31}$ Tremor (36\%) and dystonia (29\%) were also commonly observed in another study. ${ }^{32}$

\section{Comparison of PMD in Children and Adults}

Among adults, the gender ratio was almost same, whereas in children boys predominated. In both the groups, the right upper limb was the most common initial body part involved. However, the clinical phenomenology differed among the two, with tremors being more common in adults and myoclonus being more common in children. Because tremors are rhythmic and require being produced continuously, it may be difficult for the children to perform. Myoclonus that are irregularand arrhythmic, occurring at varying periods, are easy to produce. Children showed a better response to placebo when compared with adults, which is difficult to explain, but it may be related to the different perception of the illness, treatment, and underlying psychology.

A comparison of other studies with the present study is given in Table 5.

\section{CONCLUSIONS}

The series presented here is the first performed in India including both an adult and pediatric population with data collected systematically and using established and well-accepted diagnostic criteria. In our study, the majority of patients were referred from different states of the country to our tertiary care center. Hence this information cannot be generalized to the general population. Because there is a paucity of studies in PMD, more research needs to be done to better understand the psychopathology and create awareness among physicians and neurologists. We firmly believe that if PMDs are diagnosed early and accurately, appropriate therapy can be instituted in a timely manner and symptoms ameliorate before the development of chronicity.

\section{Disclosures}

YCJR served as a principal investigator for and received a research grant from the Indian Council of Medical Research, Department of Science and Technology, and the Department of Biotechnology and an advisor for and honoraria from GSK Pharmaceuticals Ltd. NK, DKP, MJ, MN, and PKP do not have anything to disclose.

\section{REFERENCES}

1. Stone J, Carson A, Duncan R, et al. Who is referred to neurology clinics? - the diagnoses made in 3781 new patients. Clin Neurol Neurosurg. 2010;112:747-51.

2. Hallet M. Physiology of psychogenic movement disorders. J Clin Neurosci. 2010;17:959-65.

3. Hinson VK, Blake WH. Psychogenic movement disorders. Lancet Neurol. 2006;5:695-700.

4. Shibasaki H, Hallett M. What is the Bereitschaftspotential? Clin Neurophysiol. 2006;117:2341-56.

5. Fahn S, Williams DT. Psychogenic dystonia. Adv Neurol. 1988;50:431-55

6. Gupta A, Lang AE. Psychogenic movement disorders. Curr Opin Neurol. 2009;22:430-6.

7. Edwards MJ, Bhatia KP. Functional (psychogenic) movement disorders: merging mind and brain. Lancet Neurol. 2012;11:250-60.

8. Lempert $\mathrm{T}$, Dieterich $\mathrm{M}$, Huppert $\mathrm{D}$, Brandt $\mathrm{T}$. Psychogenic disorders in neurology: frequency and clinical spectrum. Acta Neurol Scand. 1990;82:335-40.

9. Marsden CD. Hysteria-a neurologist's view. Psychol Med. 1986; 16:277-88.

10. Factor SA, Podskalny GD, Molho ES. Psychogenic movement disorders: frequency, clinical profile, and characteristics. J Neurol Neurosurg Psychiatry. 1995;59:406-12.

11. Kim YJ, Pakiam ASI, Lang AE. Historical and clinical features of psychogenic tremor: a review of 70 cases. Can J Neurol Sci. 1999;26:190-5.

12. Ertan S, Uluduz D, Ozekmekci S, et al. Clinical characteristics of 49 patients with psychogenic movement disorders in a tertiary clinic in Turkey. Mov Disord. 2009;24:759-62.

13. Thomas M, Vuong KD, Jankovic J. Long-term prognosis of patients with psychogenic movement disorders. Parkinsonism Relat Disord. 2006;12:382-7.

14. Fasano A, Valadas A, Bhatia KP, et al. Psychogenic facial movement disorders: clinical features and associated conditions. Mov Disord. 2012;27:1544-51.

15. Kranick S, Ekanayake V, Martinez V, Ameli R, Hallett M, Voon V. Psychopathology and psychogenic movement disorders. Mov Disord. 2011;26:1844-50.

16. Pareés I, Kojovic M, Pires C, et al. Physical precipitating factors in functional movement disorders. J Neurol Sci. 2014;338:174-7.

17. Deuschl G, Koster B, Lucking CH, Scheidt C. Diagnostic and pathophysiological aspects of psychogenic tremors. Mov Disord. 1998;13:294-302.

18. Shill H, Gerber P. Evaluation of clinical diagnostic criteria for psychogenic movement disorders. Mov Disord. 2006;21: 1163-8.

19. Lang AE. General overview of psychogenic movement disorders: eepidemiology, diagnosis and prognosis. In: Hallett M, Fahn S, Jankovic J, Lang AE, Cloninger CR, Yudofsky SC, editors. Psychogenic movement disorders. Neurology and neuropsychiatry. Philadelphia, PA: AAN Press, Lippincott Williams \& Wilkins; 2006, p. 35-41.

20. Munhoz RP, Zavala JA, Becker N, Teive HA. Cross-cultural influences on psychogenic movement disorders-a comparative review with a Brazilian series of 83 cases. Clin Neurol Neurosurg. 2011;113:115-8 
21. Ganos C, Aguirregomozcorta M, Batla A, Stamelou M, Schwingenschuh P, Münchau A, et al. Psychogenic paroxysmal movement disorders-clinical features and diagnostic clues. Parkinsonism Relat Disord. 2014;20:41-6.

22. Lang AE, Koller WC, Fahn S. Psychogenic parkinsonism. Arch Neurol. 1995;52:802-10.

23. Williams DT, Ford B, Fahn S. Phenomenology and psychopathology related to psychogenic movement disorders. Adv Neurol. 1995;65:231-57.

24. Feinstein A, Stergiopoulus V, Fine J, Lang AE. Psychiatric outcome in patients with a psychogenic movement disorder: a prospective study. Neuropsychiatry Neuropsychol Behav Neurol. 2001;14:169-76.

25. Ranawaya R, Riley D, Lang AE. Psychogenic dyskinesias in patients with organic movement disorders. Mov Dis. 1990;5:127-33.

26. Monday K, Jankovic J. Psychogenic myoclonus. Neurol. 1993;43: 349-52.
27. Voon V, Brezing C, Gallea C, Hallett M. Aberrant supplementary motor complex and limbic activity during motor preparation in motor conversion disorder. Mov Disord. 2011;26:2396-403.

28. Ferrara J, Jankovic J. Psychogenic movement disorders in children. Mov Dis. 2008;23:1875-81.

29. Schwingenschuh P, Pont-Sunyer C, Surtees R, Edwards MJ, Bhatia KP. Psychogenic movement disorders in children: a report of 15 cases and a review of the literature. Mov Disord. 2008;23:1882-8.

30. Leary PM. Conversion disorder in childhood-diagnosed too late, investigated too much? J R Soc Med. 2003;96:436-8.

31. Faust J, Soman TB. Psychogenic movement disorders in children: characteristics and predictors of outcome. J Child Neurol. 2012;27:610-4.

32. Canavese C, Ciano C, Zibordi F, Zorzi G, Cavallera V, Nardocci N. Phenomenology of psychogenic movement disorders in children. Mov Disord. 2012;27:1153-7. 